\title{
ASESMENT PENDIDIKAN KARAKTER DAN MORAL ANAK USIA DINI DENGAN BASIS KEARIFAN LOKAL
}

\author{
Didik Iswahyudi, Mochammad Ramli Akbar \\ Universitas Kanjuruhan Malang \\ ramleyakbar@gmail.com
}

\begin{abstract}
This study aims to assess and describe the process of character education and moral of early childhood with the basis of local wisdom to know the advantages and disadvantages of strategies and processes that have been applied. This research uses the qualitative case study method, \& using Miles \& Hubberman model analysis technique. This research was conducted in Bandungrejosari Village, Malang City. Based on the research conducted on the advantages of learning process of character and morale of early child have superiority in theme and design which is not in conflict with vision, mission, and goals either from institution or from regulation and appeal from stakeholder, compiled together by all parties with local wisdom identification capital sourced from existing local content and implemented in a varied and comprehensive manner through careful planning and monitoring of joint evaluations. While the weakness of the design is the process of character and moral learning that exist in the location of research is the element of subjectivity of teachers who are still high and the limited resources to explore, analyze, and identify local wisdom from local content so that the character and morale are trying to be formed still at the limit of applying local content and have not formed personality based on local wisdom.
\end{abstract}

Keywords: Moral, Character, Local Content, Local Wishdom

\begin{abstract}
ABSTRAK
Penelitian ini bertujuan untuk asesmen dan mendeskripsikan proses pendidikan karakter anak usia dini berdasarkan kearifan lokal untuk mengetahui keunggulan dan hambatan pada strategi dan proses yang sudah dilaksanakannya. Penelitian ini menggunakan metode kualitatif dengan model analisis Miles \& Hubberman. Penelitian ini dilaksanakan di Kelurahan Bandungrejosari Kota Malang. Berdasarkan penelitian yang sudah dilaksanakan keunggulan dari model pembelajaran karakter berbasis kearifan lokal yang sudah dilaksanakan yaitu pada proses pembelajaran karakter dan moral anak usia dini memiliki keunggulan pada tema dan rancangan yang tidak satupun bertentangan dengan visi, misi, dan tujuan baik dari lembaga maupun dari peraturan serta himbauan dari stakeholder, yang disusun bersama oleh semua pihak dengan modal identifikasi kearifan lokal yang bersumber dari muatan lokal yang ada dan dilaksanakan dengan cara yang variatif dan komprehensif melalui perencanaan yang matang dan monitoring evaluasi bersama. Sedangkan kelemahan dari proses pembelajaran karakter dan moral yang ada pada lokasi penelitian adalah unsur subyektifitas dari guru yang masih tinggi serta keterbatasan sumber untuk menggali, menganalisis, dan mengidentifikasi kearifan lokal dari muatan lokal sehingga karakter dan moral yang berusaha dibentuk masih pada batas menerapkan muatan lokal dan belum membentuk kepribadian dengan dasar kearifan lokal.
\end{abstract}

Keywords: Moral, Karakter, Muatan Lokal, Kearifan Lokal 


\section{PENDAHULUAN}

Watak dan karakter yang kuat adalah amanah dari Undang-Undang Republik Indonesia Nomor 20 Tahun 2003 tentang Sistem Pendidikan Nasional (Sisdiknas). Karakter adalah cara berpikir dan berperilaku yang menjadi ciri khas tiap individu untuk hidup dan bekerja sama. Individu yang berkarakter baik adalah individu yang dapat membuat keputusan dan siap mempertanggungjawabkan akibatnya. Proses membangun karakter pada anak juga ibarat mengukir atau memahat jiwa sedemikian rupa, sehingga "berbentuk" unik, menarik, dan berbeda antara satu dengan yang lain. Setiap orang memiliki karakter berbeda-beda. Ada orang yang berperilaku sesuai dengan nilai-nilai, ada juga yang berperilaku negatif atau tidak sesuai dengan nilainilai yang berlaku dalam budaya setempat (tidak/belum berkarakter atau "berkarakter" tercela). Dengan demikian, dalam pendidikan karakter, setiap anak memiliki potensi untuk berperilaku positif atau negatif. Jika ibuayah membentuk karakter positif sejak anak usia dini, maka yang berkembang adalah perilaku positif tersebut. Jika tidak, tentu yang akan terjadi sebaliknya (Nana Prasetyo, 2011).

Lickona (1992) juga menekankan pentingnya tiga komponen karakter yang baik yaitu pengetahuan tentang moral (moral knowing), perasaan tentang moral (moral feeling), dan perbuatan bermoral (moral action). Dalam hal moral knowing, terdapat enam hal sebagai tujuan diajarkannya pendidikan moral, yaitu kesadaran moral (moral awareness), pengetahuan tentang nilai moral (knowing moral values), penerimaan perspektif (perspective taking), alasan tentang moral (moral reasoning), pengambilan keputusan (decision making) dan pemahaman diri (self-knowledge). Sementara pada moral feeling terdapat enam aspek emosi yang diharapkan dapat dicapai seseorang untuk menjadi manusia berkarakter yaitu: kesadaran (conscience), harga diri (self-esteem), empati (empathy), menyukai kebaikan (loving the good), kontrol diri (self-control), dan kerendahan hati (humility). Sedangkan moral action merupakan hasil dari dua komponen karakter sebelumnya.

Menurut Julianto (2011) keperluan akan stimulasi fisik dan mental juga merupakan aspek penting dalam pembentukan karakter anak. Tentu saja hal ini memerlukan perhatian yang besar dari orang tua dan reaksi timbal balik antara ibu dan anaknya. Menurut pakar pendidikan anak, seorang ibu yang sangat perhatian (yang diukur dari seringnya ibu melihat mata anaknya, mengelus, menggendong, dan berbicara kepada anaknya) terhadap anaknya yang berusia usia di bawah enam bulan akan mempengaruhi sikap bayinya sehingga menjadi anak yang gembira, antusias mengeksplorasi lingkungannya, dan menjadikannya anak yang kreatif.

Secara kultural, masyarakat Indonesia memiliki modal karakter dan moral yang kuat yang berasal dari kebinekaan dan keragaman nilai dan budaya. Nilai dan budaya yang terkandung di masyarakat tetap utuh bertahan dengan pelestarian kearifan lokal yang terintegrasi dengan pendidikan. Khususnya untuk PAUD, kearifan lokal masih banyak difokuskan pada pengenalan-pengenalan budaya, namun secara tidak sadar, guru-guru PAUD juga memiliki keteladanan untuk pembangunan karakter anak usia dini dengan basis kearifan lokal. Dengan pertimbangan diatas maka peneliti mengambil judul penelitian Asesment Pendidikan Karakter dan Moral Anak Usia Dini dengan Basis Kearifan Lokal. 
Fokus penelitian ini adalah asesment model pendidikan karakter dan moral anak usia dini dengan basis kearifan lokal yang mencakup: (1) Bagaimanakah proses pendidikan karakter dan moral anak usia dini? (2) Bagaimanakah strategi dan proses integrasi kearifan lokal dengan model pembelajaran anak usia dini di lembaga? (3) Bagaimanakah proses pendidikan karakter dan moral dengan basis kearifan lokal anak usia dini di lembaga?

\section{METODE}

Penelitian dilakukan dengan menggunakan metode kualitatif yang bertujuan untuk memahami konteks alami dan memahami subjek penelitian secara mendalam dan bersifat interpretatif, artinya mencari temukan fakta (Putra, 1994:67). Metode pendekatan penelitian yang digunakan adalah metode kualitatif naturalistik. Metode ini dipilih karena peneliti ingin melihat langsung berbagai kenyataan dilapangan yang dilakukan subjek penelitian tanpa menambah atau merubah peristiwa yang terjadi dilapangan atau berusaha memahami perilaku subjek penelitian dari segi kerangka berpikir maupun bertindak dari subjek penelitian itu sendiri (Moleong, 2010:31).

Teknik pengumpulan data yang digunakan adalah wawancara, observasi, FGD, dan analisis dokumentasi. Analisis data pada penelitian ini menggunakan model Miles \& Huberman (Putra, 1994:67). Menurut Miles dan Huberman ada 4 (empat) macam kegiatan dalam analisis data kualitatif, yaitu pengumpulan data, reduksi data, model data dan penarikan/verifikasi kesimpulan, yang dapat digambarkan dengan model interaktif sebagai berikut (Miles, 1984:20):

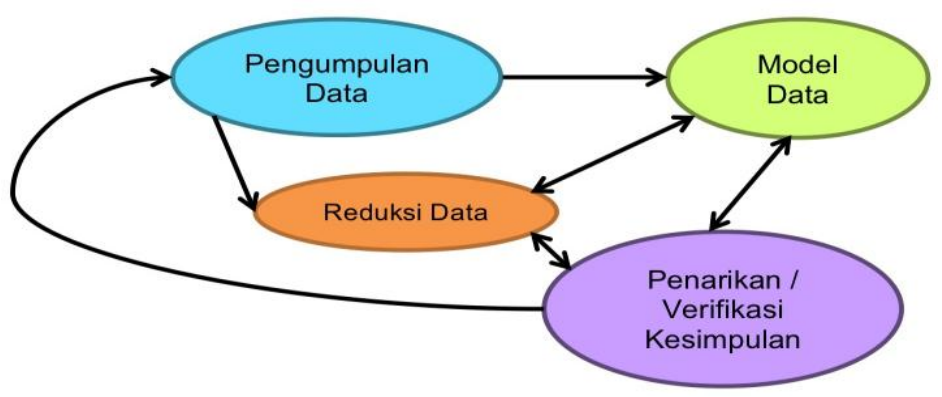

Untuk memperoleh keabsahan data, peneliti menggunakan 3 (tiga) teknik pemeriksaan keabsahan data, yaitu: triangulasi, pemeriksaan sejawat melalui diskusi, dan auditing.

\section{HASIL DAN PEMBAHASAN}

Berdasarkan hasil observasi, wawancara, dan analisis dokumen yang ada, dengan subyek informan, diperoleh data model pendidikan karakter dan moral anak usia dini dengan basis kearifan lokal yang mencakup: (1) rangkaian proses pendidikan karakter dan moral anak usia dini (2) strategi dan proses integrasi kearifan lokal dengan model pembelajaran anak usia dini di lembaga (3) proses pendidikan karakter dan moral dengan basis kearifan lokal anak usia dini di lembaga. 


\section{Proses Pendidikan Karakter dan Moral Anak Usia Dini}

Rangkaian proses pendidikan karakter dan moral anak usia dini di lingkungan Gugus Sekolah Bandungrejosari Kota Malang berjalan dengan cara yang cukup komprehensif dengan 3 (tiga) kelemahan. Rangkaian proses pendidikan karakter dan moral untuk anak usia dini di lokasi penelitian, diawali dengan menterjemahkan visi misi dan tujuan umum dari serta pencapaian hasil pembelajaran sesuai Sisdiknas 2003, tujuan dan pencapaian yang dianjurkan oleh pimpinan daerah dan lembaga melalui rapat-rapat, seminar, dan diskusi sebelum pelaksanaan pembelajaran di awal tahun ajaran. Dari penterjemahan tersebut, guru-guru dalam gugus sekolah memberikan tanggapan dan menganalisis karakter dan moral yang dikehendaki dan model pembelajaran yang akan diterjemahkan dalam Program Tahunan (Prota), Rencana Pembelajaran Semester (RPS), Rencana Pembelajaran Mingguan (RPM), dan Rencana Pelaksanaan Pembelajaran Harian (RPPH). Untuk penyusunan prota sampai dengan RPPH yang dilaksanakan oleh guru, masing-masing lembaga juga masih menyesuaikan model karakter dengan visi misi dan tujuan dari basis lembaga pendidikan yang ada secara spesifik, melalui pembahasan dengan masing-masing pimpinan lembaga. Model atau karakter dan moral yang sudah dipilih dari gugus sekolah tidak serta merta akan dilaksanakan pada semua aspek, namun masih membutuhkan analisis dan screening untuk disesuaikan dengan visi misi dan tujuan lembaga. Proses selanjutnya setelah model karakter dan moral yang akan dikembangkan pada proses pembelajaran oleh guru didapatkan, guru di kelas menganalisis dan mengintegrasikannya dengan muatan lokal yang dapat dilaksanakan dalam proses pembelajaran melalui tema-tema dalam rencana pembelajaran. Proses pembelajaran yang dilaksanakan oleh guru untuk karakter dan moral yang ada masih menggunakan pola yang tidak berubah sejak guru mengawali profesinya yaitu dengan metode keteladanan, bermain peran, dan sosiodrama. Untuk proses dan alur pendidikan karakter dan moral yang ada, dapat dilihat pada gambar berikut:

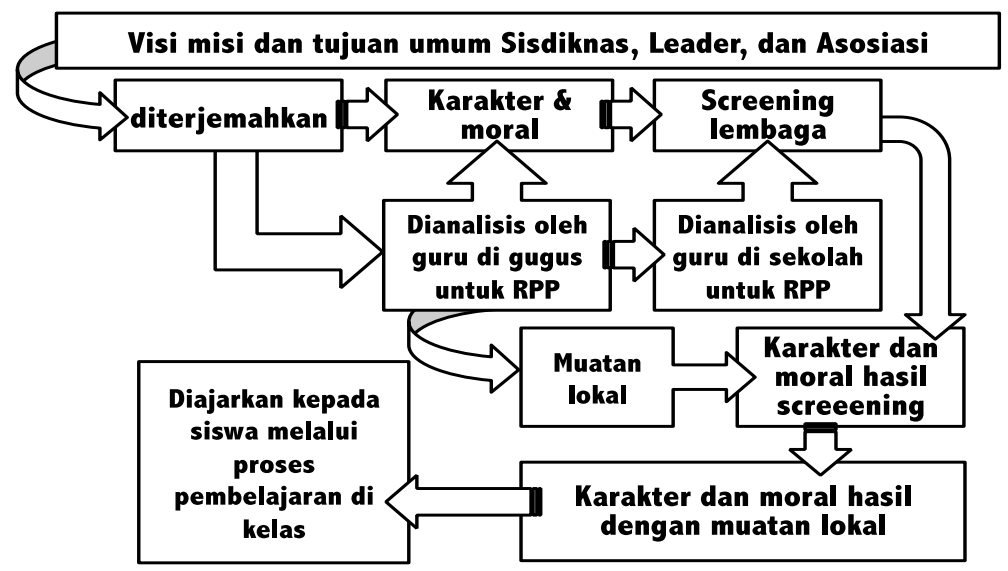

Gambar 1. Proses Pendidikan Karakter dan Moral Anak Usia Dini

Berdasarkan identifikasi proses yang ada untuk kemudian dianalisis oleh peneliti, kelebihan dari proses tersebut adalah: (1) karakter dan moral yang akan dibangun pada anak di masing-masing anggota gugus sekolah tidak bertentangan dengan undang-undang dan tujuan pendidikan nasional. Selain itu, (2) karakter dan moral yang akan dibangun oleh guru di masing-masing sekolah juga dapat dibantu bersama 
dengan anggota guru pada gugus yang sama. Sedangkan kelemahan utama dari proses pendidikan karakter yang ada adalah: (1) guru-guru menterjemahkan dengan caranya sendiri dalam mengaplikasikan model karakter dan moral yang akan diberikannya, dan penilaian serta analisis yang subyektif yang ada masih tinggi. Dengan tingginya subyektifitas guru dalam menterjemahkan pendidikan karakter dan moral tersebut tidak dibarengi dengan evaluasi oleh guru-guru lain secara obyektif melalui monitoring dan evaluasi atau feedback dari berbagai meeting atau diskusi yang sudah diselenggarakan oleh gugus sekolah. Kelemahan selanjutnya adalah: (2) muatan lokal yang diintegrasikan pada pembelajaran murid di sekolah, tidak berasal dari analisis dan identifikasi secara komprehensif, namun cukup diterjemahkan oleh guru dari pandangan umumnya dan analisis subyektif dari guru saat akan melaksanakan proses pembelajaran. Guru-guru belum mengidentifikasi dan menganalisis konten karakter dan moral dari muatan lokal yang dapat diangkat melalui pembahasan dengan pakar atau sumber yang valid dan reliabel. Subyektifitas guru dalam menganalisis muatan lokal masih tinggi, dan masih terdapat guru yang memiliki hambatan menterjemahkan muatan lokal dalam proses pembelajaran karena keterbatasan pemahaman guru yang berasal dari luar daerah sekolah.

\section{Strategi dan Proses Integrasi Kearifan Lokal}

Rangkaian proses mengintegrasikan kearifan lokal dalam proses pembelajaran oleh guru di kelas, diawali dengan mengidentifikasi dan menganalisis muatan lokal yang ada. Dari muatan lokal yang ada, kemudian diterjemahkan dan aplikasi proses pembelajaran yang bisa dilaksanakan oleh guru dalam kelas seperti kebudayaan dan seni. Kearifan lokal yang ada diterjemahkan sebagai kegiatan seni dan budaya yang dapat dilaksanakan melalui kegiatan-kegiatan yang bernuansa kebudayaan seperti tarian dan nyanyian. Dalam menterjemahkan muatan lokal, guru-guru dibantu oleh team di sekolah, terutama untuk perencanaan kegiatan yang akan dilaksanakan oleh guru. Monitoring dan evaluasi yang dilaksanakan oleh guru dalam menentukan kegiatan yang bernuansa muatan lokal dilaksanakan saat pembahasan sampai dengan menyusun perencanaan kegiatan pembelajaran. Rangkaian proses tersebut dapat dilihat pada gambar berikut:

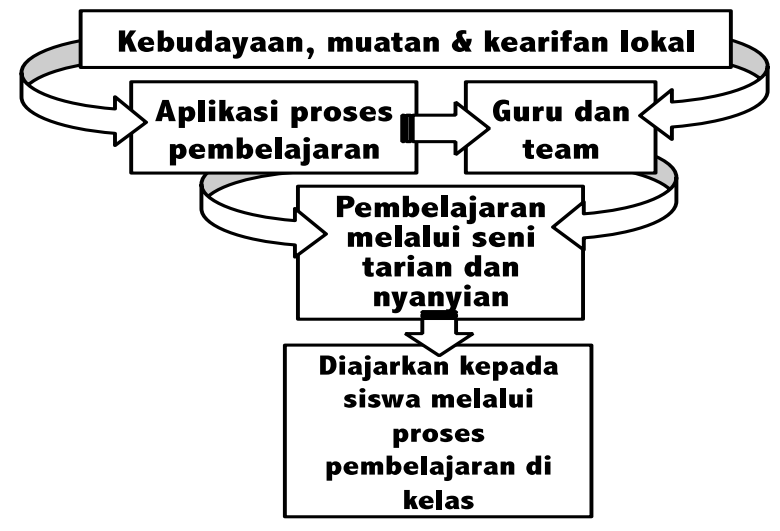

Gambar 2. Strategi dan Proses Integrasi Kearifan Lokal 
Berdasarkan rangkaian dan proses integrasi kearifan lokal pada kegiatan pembelajaran yang ada, strategi tersebut memiliki keunggulan yaitu: (1) kearifan lokal yang diidentifikasi dari muatan lokal secara spesifik oleh guru, berdasarkan hasil analisis dan identifikasi bersama dari team sekolah memiliki kemurnian tersendiri dari daerah lembaga, sehingga ciri khas dari masing-masing muatan lokal satu sekolah dengan sekolah yang lain dalam satu gugus memiliki ciri khas tersendiri. Keunggulan selanjutnya adalah (2) analisis dan identifikasi kearifan lokal yang berasal dari muatan lokal mampu diterjemahkan dan dilaksanakan dengan baik oleh guru dalam proses pembelajaran. Sedangkan untuk kelemahan strategi integrasi kearifan lokal pada proses pembelajaran adalah (1) guru-guru yang belum mampu memilah kearifan lokal dan budaya lokal, sehingga kearifan lokal yang ada belum bernuansa karakter dan moral dari sekitar. Guru-guru masih memandang kearifan lokal adalah muatan lokal dan sikap sehari-hari, sehingga kepribadian yang membentuk karakter dan moral yang khas dari masing-masing daerah belum nampak dengan baik. Kelemahan selanjutnya adalah (2) subyektifitas dari guru-guru sekolah masih sangat terlihat dari pilihan karakter dan kearifan lokal yang dianalisis oleh guru-guru. Guru-guru belum menggali dan menganalisis kearifan lokal dari sumber atau referensi yang komprehensif. Pembahasan muatan lokal dan kearifan lokal masih pada aktifitas diskusi internal dan terbatas oleh guru dalam lingkungan lembaga yang sama, dan belum bekerjasama dengan sesepuh, budayawan lokal, tokoh masyarakat dan belum mengacu pada referensi buku, penelitian, maupun jurnal yang mendukung.

\section{Proses Pendidikan Karakter dan Moral dengan Basis Kearifan Lokal}

Proses dan rangkaian edukasi dan pembelajaran untuk membangun karakter anak usia dini dengan basis kearifan lokal di lokasi penelitian, dilaksanakan sesuai dengan proses perencanaan pembelajaran yang sudah disusun. Proses yang dilaksanakan terbagi atas 3 (tiga) cara yaitu melalui seni peran, sosio drama, dan keteladanan. Dari ketiga proses tersebut, seni peran dan sosiodrama memiliki rancangan yang sama yaitu perencanaan tema untuk kegiatan pembelajaran kelompok. Pembelajaran karakter dan moral dengan tema kearifan lokal disesuaikan dengan RPS dan RPP yang sudah ada. Kearifan lokal bersifat mendukung tema utama dari seni peran dan sosiodrama yang dilaksanakan oleh guru dan siswa. Pembelajaran melalui sosiodrama dan seni peran diakhiri dengan refleksi dan masing-masing siswa mendeskripsikan peran, sifat, sikap dan perilaku yang sudah dilaksanakan dalam seni peran dan drama. Kearifan lokal secara khusus dibahas saat refleksi dengan cara mendeskripsikan perilaku yang ideal dan evaluasi dari apa yang sudah dilaksanakan oleh murid dalam sosiodrama dan seni peran tersebut. Rangkaian proses tersebut dapat dilihat pada gambar berikut: 


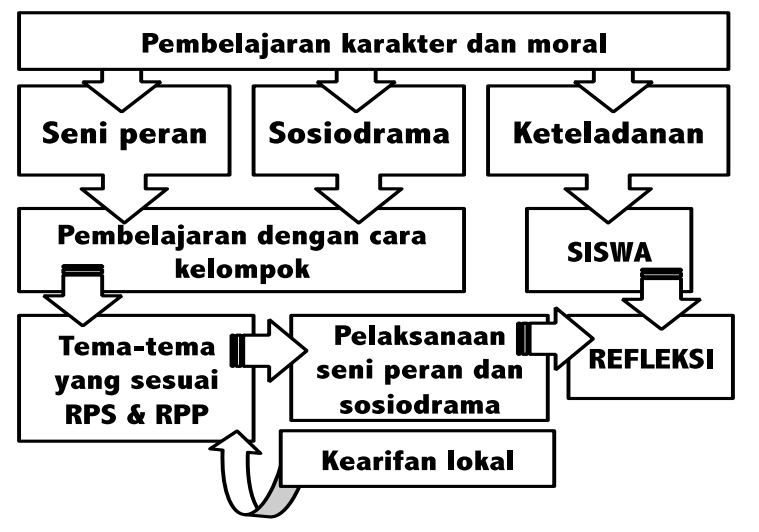

Gambar 3. Proses Pendidikan Karakter dan Moral dengan Basis Kearifan Lokal

Dari proses tersebut, keunggulan yang nampak adalah (1) proses pembelajaran karakter dan moral anak usia dini berbasis kearifan lokal mampu dilaksanakan dengan cara yang variatif dan tidak monoton. Sosiodrama dan seni peran yang dipilih oleh guru dalam penerapan pembelajaran karakter berbasis kearifan lokal memiliki kekayaan tema yang komprehensif. Model pembelajaran yang dilaksanakan oleh guru juga memiliki rancangan dan model yang detail. Keunggulan lain adalah (2) karakter dan moral yang dibangun oleh guru untuk anak usia dini di lokasi penelitian sudah memiliki rancangan pembangunan kepribadian yang detail dengan rutinitas dan aktifitas seni peran dan sosiodrama yang memiliki porsi yang seimbang dengan pembangunan motorik dan kognitif anak usia dini. Pengembangan dan pembangunan karakter anak usia dini juga memiliki prasarana dan sarana (sudut sosiodrama dan peran, sudut mikro dan makro) yang sudah komprehensif. Untuk kelemahan dari proses pembelajaran karakter dan moral dengan basis kearifan lokal untuk anak usia dini yaitu: (1) kearifan lokal yang diintegrasikan dengan pembelajaran karakter dan moral melalui seni peran dan sosiodrama belum menjadi tema utama yang mampu menjadi fokus pembangunan dan pengembangan kepribadian dari anak usia dini. Kearifan lokal yang ada masih bersifat mendukung tema RPS dan RPP, dan bernuansa kelembagaan yang dominan. Kelemahan lain dalam pembelajaran karakter dan moral anak usia dini adalah (2) identifikasi karakter dan sikap yang diberikan dalam proses pembelajaran karakter dan moral anak usia dini masih belum menyentuh kepribadian secara mendasar dengan kearifan lokal yang ada. Sikap dan perilaku yang berusaha dibentuk oleh guru masih pada sikap dan perilaku umum seperti kesopanan dan kedisiplinan, dan belum menyentuh kepada kepribadian yang didasarkan pada kearifan lokal seperti misalnya gotong royong.

\section{PENUTUP}

\section{Simpulan}

Berdasarkan penelitian yang sudah dilaksanakan, asesmen pada proses dan strategi pembelajaran karakter dan moral anak usia dini berbasis kearifan lokal memiliki kelebihan dan kelemahan dari masing-masing perspektif proses dan fokus. Proses pembelajaran karakter dan moral anak usia dini memiliki keunggulan pada tema dan rancangan yang tidak satupun bertentangan dengan visi, misi, dan tujuan 
baik dari lembaga maupun dari peraturan serta himbauan dari stakeholder, yang disusun bersama oleh semua pihak dengan modal identifikasi kearifan lokal yang bersumber dari muatan lokal yang ada dan dilaksanakan dengan cara yang variatif dan komprehensif melalui perencanaan yang matang dan monitoring evaluasi bersama. Sedangkan kelemahan dari proses pembelajaran karakter dan moral yang ada pada lokasi penelitian adalah unsur subyektifitas dari guru yang masih tinggi serta keterbatasan sumber untuk menggali, menganalisis, dan mengidentifikasi kearifan lokal dari muatan lokal sehingga karakter dan moral yang berusaha dibentuk masih pada batas menerapkan muatan lokal dan belum membentuk kepribadian dengan dasar kearifan lokal. Kearifan lokal juga belum menjadi tema utama untuk membentuk kepribadian anak secara mendasar dalam pembelajaran. Kelemahankelemahan yang ada bisa diatasi dengan lebih mengaktifkan guru dan sekolah dalam mencari sumber muatan lokal dan kearifan lokal dengan lebih detail pada tokoh masyarakat dan referensi yang terpercaya. Kelemahan lain juga bisa diatasi dengan peningkatan kemampuan guru dan sekolah untuk menganalisis karakter, kepribadian, dan sikap dengan lebih mendasar pada aspek psikologis.

\section{Rekomendasi}

Proses pembelajaran karakter anak usia dini dengan basis muatan lokal akan lebih baik jika dilaksanakan melalui identifikasi dan analisis secara mendalam pada muatan dan kearifan lokal dari daerah lembaga pendidikan berada kemudian disinergikan dengan rancangan tujuan, pokok pikiran dan visi misi lembaga-lembaga terkait. Penelitian selanjutnya dirancang untuk meningkatkan proses pembelajaran karakter anak usia dini dengan basis muatan lokal yang memiliki sumber kearifan lokal yang lebih komprehensif.

\section{DAFTAR RUJUKAN}

Lickona, T. (1992). Educating for Character, How Our Schools Can Teach Respect and Responsibility. New York : Bantam Books.

Miles, Matthew B. dan Huberman, A. Michael. (1984). Qualitative Data Analysis: A Source Book of New Methods, London: Sage Publications.

Moleong, Lexy J. (2010). Metodologi Penelitian Kualitatif, Bandung: Remaja Rosdakarya.

Putra, Nusa. (2012). Penelitian Kualitatif PAUD - Pendidikan Anak Usia Dini. Jakarta: Rajawali Pers.

Prasetyo, Nana. (2011). Membangun Karakter Anak Usia Dini. Direktorat Jenderal Pendidikan Anak Usia Dini Nonformal dan Informal, Kementerian Pendidikan Nasional.

Jurnal :

Julianto. (2011). Peranan Keluarga dalam Pendidikan Karakter Anak pada Era Globalisasi. Jurnal Psikologi Pendidikan, DP. Jilid 11, Bil 1/2011, UNSRI. Palembang. 